\title{
Water use, transpiration efficiency and yield in cowpea (Vigna unguiculata) and peanut (Arachis hypogaea) across water regimes
}

\author{
Oumarou Halilou $^{\mathrm{A}, \mathrm{B}}$, Falalou Hamidou ${ }^{\mathrm{A}, \mathrm{B}}$, Boulama Katzelma Taya ${ }^{\mathrm{A}}$, Saadou Mahamane ${ }^{\mathrm{B}}$, \\ and Vincent Vadez ${ }^{\mathrm{C}, \mathrm{D}}$ \\ Anternational Crops Research Institute for the Semi-Arid Tropics, Sahelian Center, Crop Physiology \\ Laboratory, Niamey, Niger. \\ ${ }^{B}$ Department of Biology, Faculty of Sciences, University Abdou Moumouni, Niamey, Niger. \\ C International Crops Research Institute for the Semi-Arid Tropics, Crop Physiology Laboratory, Patancheru, \\ Greater Hyderabad, Telangana, India. \\ ${ }^{D}$ Corresponding author. Email: v.vadez@cgiar.org
}

\begin{abstract}
Genotypic variation in crop response to drought depends on agronomic, environmental and genetic factors, and only limited work has compared responses of crop species to water limitation. Twenty genotypes of peanut (Arachis hypogaea L.) and of cowpea (Vigna unguiculata (L.) Walp) were tested in lysimeters under well-watered (WW) and water-stress (WS) conditions during two seasons, a post-rainy season with high evapotranspiration and a rainy season with low evapotranspiration (ET), in order to assess: $(i)$ variability in the agronomic response to stress within and between species across the seasons; (ii) the water requirement of the two crops in each season; and (iii) the stress effect on harvest index (HI), transpiration efficiency (TE), pod yield and haulm yield. Cowpea required less water than peanut during the two seasons, and water use in cowpea varied less across seasons than in peanut. Peanut yield was more sensitive to water stress than cowpea yield, although its water use under WS was higher than in cowpea. Also, under WS conditions, TE, HI and pod yield were more stable across season in cowpea than in peanut. In the post-rainy season, the decrease in pod yield and $\mathrm{HI}$ under WS was higher in peanut ( $95 \%$ and $80 \%$, respectively) than in cowpea ( $70 \%$ and $35 \%)$. In addition, TE was less affected by WS in cowpea (5\%) than in peanut $(24 \%)$. HI explained a large part of yield variation in both crops, especially under WS. Under WW, water use explained a large portion of the residual yield variations unexplained by HI, although TE also explained a substantial part of the variation in cowpea. Under WS, the main determinant of residual yield variations in both crops was TE. Generally, genetic variation for water use, TE and HI was found in both species across water regimes and seasons. A notable exception was the absence of variation in peanut water use and TE in the rainy season. Our results showed that cowpea, with lower water requirement and efficient water use under a high-ET season, was more resilient to water-limited and high-ET conditions than peanut.
\end{abstract}

Additional keywords: agronomic components, cowpea, drought, groundnut, lysimeters, peanut, water use.

Received 8 July 2014, accepted 4 February 2015, published online 4 June 2015

\section{Introduction}

Peanut (also known as groundnut, Arachis hypogaea L.) and cowpea (Vigna unguiculata (L.) Walp) are economically important legumes supplying major dietary protein compared with animal resources. About $90 \%$ of total peanut production across the world comes from tropical regions (in Asia and Africa), with $60 \%$ from semi-arid tropics. Crops are often subjected to drought stress at any growth stage, leading to great loss of grain yield and biomass. Cowpea and peanut are considered droughttolerant crops (Ehlers and Hall 1997; Singh et al. 1999; Dadson et al. 2005). However, erratic rainfall and short rainy seasons negatively affect their productivity in semi-arid tropical areas. Although terminal drought is predominant in the semi-arid tropics, drought can affect cowpea at any time (Ahmed and Suliman 2010; Sanda and Maina 2013). Previous studies have reported genotypic variation in cowpea under terminal drought (Ahmed and Suliman 2010; Sanda and Maina 2013; Belko et al. 2014). Peanut has a longer crop cycle than cowpea and faces both intermittent and terminal drought stress (Ratnakumar and Vadez 2011). Genotypic variation for grain yield in peanut genotypes under intermittent drought has been reported (Hamidou et al. 2012). Therefore, differences in water requirement surely exist between peanut and cowpea, mainly due to difference in cycle duration, but no accurate estimation exists of these water-need differences, their variation across seasons, and their variation within species.

Much effort is being made to reduce water use by crops and produce 'more crop per drop' (Morison et al. 2008). Under these circumstances, managing crop water use so that the crop reaches maturity is crucial (Vadez et al. 2013). Transpiration efficiency 
(TE), i.e. the ratio of mass accumulation to transpiration, is an important component of water-use efficiency (WUE) and a possible source of yield variation under drought stress in various crops. For instance, it contributes to higher yields in peanut under intermittent drought (Ratnakumar et al. 2009) and in sorghum under terminal drought (Vadez et al. 2011a). However, TE is complex and depends on physiological and environmental variables (Sinclair 2012). Therefore, comparison of TE data across experiments within a given crop is difficult to make, and even more difficult when the comparison is between crops species. Although a few authors consider that TE should theoretically not vary within $\mathrm{C}_{3}$ and $\mathrm{C}_{4}$ plants (Steduto et al. 2007; DeLucia et al. 2014), meaning that TE of peanut and cowpea should be similar, many reports demonstrate genetic differences in TE among species (Pandey et al. 1987; Tomás et al. 2014). Using a lysimeter system allowing the monitoring of plant transpiration throughout the entire crop cycle, large variation has been found within species (e.g. Vadez et al. $2011 b$ ). In the present study, we use the same experimental approach to assess TE of two species; cowpea and peanut, cultivated side-by-side under the same experimental conditions and during the same season, and then assess the range of TE variation within and between species.

Increasing water uptake from the soil profile is also essential for growth and production under limited water availability, and drought tolerance could derive from the ability of the crop to extract water from the entire soil profile (Wright and Nageswara Rao 1994; Blum 2009). In peanut, enhanced root development has been reported to provide better water extraction (Jongrungklang et al. 2011) and sometimes leads to higher yield under drought. However, a poor relationship between root length density and water extraction was reported in peanut (Ratnakumar and Vadez 2011). Therefore, measuring plant water uptake in vivo over the entire life of the crop may provide better information on the functional role of roots (Vadez et al. 2007a, 2008). Because of the difficulty of assessing plant water use in the field, high-throughput lysimetric methods have been developed (Vadez et al. 2008, 2014; Zaman-Allah et al. 2011) to improve our knowledge of the water requirements of many crops and of the range of variation within species.

Here, we compare these water requirements in peanut and cowpea. We also used the system to analyse each component of the conceptual framework of Passioura (1977), $\mathrm{Y}=\mathrm{T} \times \mathrm{TE} \times \mathrm{HI}$, defining crop yield (Y) as a function of crop harvest index (HI), the amount of transpired water $(\mathrm{T})$ and TE to compare the importance of each term of the equation in the two species. We hypothesise that TE would be an important yield-determining factor in both of these crops, which are adapted to the Sahel (the semi-arid zone extending across Northern Africa, south of the Sahara Desert), and we expect that water requirement differences would depend on season and water regime. Therefore, we tested whether there were relationships between these integrative traits and yield, how close these relationships would be, and whether they were species-specific. The objectives of this work were to $(i)$ compare the peanut and cowpea agronomic response to drought in two seasons varying in their evapotranspiration (ET) under lysimetric conditions; ( $i$ i) investigate water requirement in peanut and cowpea; and (iii) assess the contribution of water use, TE and
$\mathrm{HI}$ in cowpea and peanut yield based on the equation of Passioura (1977).

\section{Materials and methods}

Experimental conditions

Experiments were conducted in a lysimetric system at the International Crop Research Institute for the Semi-Arid Tropics (ICRISAT), Sahelian Centre (Sadoré, $45 \mathrm{~km}$ south of Niamey city, Niger; $13^{\circ} \mathrm{N}, 2^{\circ} \mathrm{E}$ ), during the post-rainy season 2012 (January-April) and the rainy season 2012 (AugustNovember). During the rainy season, a rainout shelter was used to protect plants from rains during drought imposition. Climatic data (temperature, humidity and ET through class A pan evaporation) were recorded daily from a meteorological station located close to our experiment.

Twenty genotypes of peanut and 20 genotypes of cowpea (Table 1), contrasting for yield under drought in the field and under controlled environment conditions (Hamidou et al. 2012; Belko et al. 2013), were sown in lysimeters. These consisted of PVC cylinders, $1.30 \mathrm{~m}$ deep and $25 \mathrm{~cm}$ in diameter, filled with a soil mixture of $60 \%$ sand, $30 \%$ clay and $10 \%$ manure. The soil was fertilised with $200 \mathrm{mg} \mathrm{kg}^{-1}$ of di-ammonium phosphate (NPK $18: 46: 0$ ). The top $3 \mathrm{~cm}$ of soil was mixed with $2 \mathrm{~g}$ carbofuran to prevent damage from soilborne pests. Between the two trials (rainy and off-season), pearl millet (Pennisetum glaucum (L.) $\mathrm{R}$.Br.) was grown in the cylinders as a fallow crop to mitigate the build-up of pathogens and pests that often occurs when one species is continuously cropped. Before sowing, the soil was irrigated (90\% field capacity), and four seeds were sown per cylinder and thinned to two plants per cylinder at 10 days after sowing (DAS). The experimental design was a randomised complete split-plot with water treatment as the main factor (well-watered, WW; water stress, WS), crop species as the sub-factor, and 20 genotypes of each species randomised within each sub-block in five replications. Cylinders were arranged in two adjacent trenches, one for WW and one for WS. One of the two plants in each cylinder was sampled before measurement of transpiration to assess initial biomass dry weight. The average dry weight of plants at that time was $7.4 \mathrm{~g} \mathrm{plant}^{-1}$ in cowpea and $5.1 \mathrm{~g} \mathrm{plant}^{-1}$ in peanut in the post-rainy season, and $6.5 \mathrm{~g} \mathrm{plant}^{-1}$ in cowpea and $4.2 \mathrm{~g} \mathrm{plant}^{-1}$ in peanut in the rainy season. Prior to weighing cylinders, the lysimeters were watered to field capacity and the soil surface was covered with a $2-\mathrm{cm}$ thick layer of polyethylene beads to minimise soil evaporation (Ratnakumar et al. 2009).

Cylinders of the WW plants were at $80 \%$ field capacity until the end of experiments. Cylinder weighing started at flowering time (50\% of plants had a first flower), when WS was imposed. This stage was chosen because previous works (Pallas et al. 1979; Turk et al. 1980; Ravindra et al. 1990; Naveen et al. 1992; Rucker et al. 1995) showed that peanut and cowpea were particularly sensitive to drought imposed at the flowering stage. In cowpea, WS was imposed at 46 and 45 DAS in the rainy and post-rainy season, respectively, by stopping irrigation. In peanut, the WS cycle started at 38 and 40 DAS in rainy and post-rainy season, respectively. Peanut plants were then exposed to an intermittent WS, typical for peanut in the rain-fed regions of the semi-arid tropics (Sharma and Lavanya 2002; Reddy et al. 2003), which 
Table 1. List of selected peanut and cowpea genotypes and an evaluation of their drought response in previous work (Belko et al. 2013; Hamidou et al. 2012)

\begin{tabular}{llll}
\hline $\begin{array}{l}\text { Cowpea entry } \\
\text { name }\end{array}$ & $\begin{array}{l}\text { Drought } \\
\text { response }\end{array}$ & $\begin{array}{l}\text { Peanut entry } \\
\text { name }\end{array}$ & $\begin{array}{l}\text { Drought } \\
\text { response }\end{array}$ \\
\hline IT84S-2049 & Tolerant & ICG 97183 & Tolerant \\
IT85F-3139 & Tolerant & ICGV 97182 & Tolerant \\
IT93K-693-2 & Tolerant & ICGV 02266 & Tolerant \\
IT98K-1105-5 & Tolerant & ICGV 02189 & Tolerant \\
Mouride & Tolerant & ICG11088 & Tolerant \\
IT93K-503-1 & Tolerant & ICG 12697 & Tolerant \\
IT96D-610 & Tolerant & ICG 8751 & Tolerant \\
IT98K-428-3 & Tolerant & ICGV 01232 & Tolerant \\
IT99K-124-5 & Tolerant & ICGV 91114 & Tolerant \\
Suvita 2 & Tolerant & 55-437 & Tolerant \\
Bambey 21 & Susceptible & ICGS 44 & Susceptible \\
UC-CB 46 & Susceptible & ICGV 00350 & Tolerant \\
IT82E-18 & Susceptible & ICG 4750 & Tolerant \\
IT84S-2246 & Susceptible & ICG 3584 & Tolerant \\
IT93K-93-10 & Susceptible & TMV2 & Susceptible \\
IT83D-442 & Susceptible & JL 24 & Susceptible \\
IT90K-284-2 & Susceptible & ICG 15287 & Tolerant \\
IT95K-1095-4 & Susceptible & ICG1834 & Susceptible \\
IT97K-556-6 & Susceptible & FLEUR 11 & Tolerant \\
KVX-525 & Susceptible & ICGV 99001 & Susceptible \\
\hline
\end{tabular}

consisted of cycles of drying and re-watering when the majority of WS plants showed clear wilting symptoms. At that time, the stress was relieved by providing $1000 \mathrm{~mL}$ of water. Given the diameter of the lysimeters, this was equivalent to $16 \mathrm{~mm}$ of water when extrapolated to a field condition. Several such cycles of stress and re-watering were applied until final harvest at maturity.

\section{Lysimeters arrangement and weighing}

Weighing of the cylinders was done by lifting them with a block-chained pulley and inserting an S-type load cell (Mettler-Toledo, Geneva, Switzerland) between the rings of the cylinder and the pulley. The scale (capacity $200 \mathrm{~kg}$ ) allowed repeated-measurements and gave an accuracy of $20 \mathrm{~g}$ on each weighing. The lysimeters were separated from one another by a distance of $\sim 5 \mathrm{~cm}$. Therefore, the peanut and cowpea crops were planted at a density of 16 plants $\mathrm{m}^{-2}$, which was close to plant density in the field $\left(20\right.$ plants $\left.\mathrm{m}^{-2}\right)$. This allowed an assessment of the water extraction pattern of a crop cultivated in conditions similar to the field.

\section{Measurements}

Cowpea was harvested at 75 DAS (30 March 2012) in the post-rainy season and at 68 DAS (17 October 2012) in the rainy season. Peanut was harvested at 96 DAS (20 April 2012) in the post-rainy season and 98 DAS (16 November 2012) in the rainy season. Plants were harvested by hand after well irrigation of the tubes to facilitate unearthing of the pods. The plants were airdried for 2 weeks and plants were separated into haulm and pod fractions.

Transpiration was measured via a gravimetric procedure, by regular weighing of the cylinders (twice per week) and accounting for possible water additions. TE was calculated as:

$$
\mathrm{TE}=(\mathrm{FDM}-\text { mean IDM }) / \mathrm{TTW}
$$

where FDM is final dry matter at harvest; mean IDM is average initial dry matter for each genotype; and TTW is total transpired water for each individual plant during the period of water-uptake monitoring, where transpiration was calculated as the difference of consecutive lysimeter weight, plus water added after the previous weighing.

Harvest index was calculated as ratio of pod weight to total biomass:

For cowpea $: \mathrm{HI}=$ pod weight $/($ pod weight + haulm weight $)$

$$
\text { For peanut: } \begin{aligned}
\mathrm{HI}= & 1.65 \times \text { pod weight } /(\text { pods weight } \times 1.65 \\
& + \text { haulm weight })
\end{aligned}
$$

The correction coefficient 1.65 was used to adjust for differences in the energy requirement of peanuts to produce pod dry matter compared with the vegetative part (Duncan et al. 1978).

\section{Statistical analyses}

Statistical analyses were performed using GeNSTAT 14th edition (VSN International Ltd, Hemel Hempstead, UK), by one-way analysis of variance (ANOVA) and $t$-test. Differences between the mean values of treatments were evaluated using 1.s.d. at $P=0.05$. A two-way ANOVA analysis was also performed to assess the effect of genotype (G), season (S) and genotype $\times$ season $(\mathrm{G} \times \mathrm{S})$ interaction for the different traits measured. Microsoft office Excel 2010 Software (Microsoft Corp., Redmond, WA, USA) was used for linear regression by plotting different traits to determine the $R^{2}$ and regression equation. GraphPad Prism version 5.00 for Windows (GraphPad Software Inc., San Diego, CA, USA) was used to test the significance of linear regression using Pearson's test.

\section{Results}

Weather

Temperature, relative humidity (RH), maximum vapour pressure deficit $\left(\mathrm{VPD}_{\max }\right.$, i.e. the VPD calculated from the daily minimum RH percentage and maximum temperature), and ET differed largely between the two seasons. During the post-rainy season, the minimum and maximum temperature ranges were $11-28^{\circ} \mathrm{C}$ and $31-44^{\circ} \mathrm{C}$, respectively, and $\mathrm{RH}$ $4-16 \%$ and $43-84 \%$. In the rainy season, the minimum and maximum temperatures ranges were $18-28^{\circ} \mathrm{C}$ and $26-39^{\circ} \mathrm{C}$, respectively, and $\mathrm{RH} 13-51 \%$ and $94-98 \%$. The $\mathrm{VPD}_{\max }$ was higher during the post-rainy season $(3.0 \mathrm{kPa}$ average, range $1.5-4.7 \mathrm{kPa})$ than during the rainy season $(1.4 \mathrm{kPa}$ average, range $0.18-0.28 \mathrm{kPa}$ ) when the air temperature was lower and RH higher (Fig. 1). Therefore, the post-rainy season was characterised by high evaporative demand and then high ET $\left(10 \mathrm{~mm} \mathrm{day}^{-1}\right.$, on average), whereas ET during the rainy season was lower (5 $\mathrm{mm} \mathrm{day}^{-1}$, on average) (Fig. 1). 


\section{Differences between peanut and cowpea}

\section{Water use and transpiration efficiency, harvest index} and pod yield

Water use of both crops was lower in the rainy season than in the post-rainy season. Under WW conditions, large differences in water use between seasons occurred in peanut, whereas differences in water use were much smaller for cowpea (Fig. 2a). Under both WW and WS and across seasons, peanut used more water than cowpea. In the post-rainy season, water use in cowpea was $61 \%$ and $57 \%$ less than in peanut under WW and WS, respectively, whereas in the rainy season it was $52 \%$ and $59 \%$ less. For both crops, TE was higher in the rainy season than in post-rainy season, and this was related to the higher $\mathrm{VPD}_{\max }$ in the post-rainy $(3 \mathrm{kPa})$ than in the rainy season $(1.4 \mathrm{kPa})$. Under WW conditions, peanut and cowpea TE values were similar in both seasons. However, under WS conditions, cowpea had higher TE than peanut in the post-rainy season, whereas peanut had higher TE than cowpea in the rainy season (Fig. 2b). Consequently, under WS conditions, the TE difference between seasons was larger in peanut than in cowpea; hence, TE was more stable across seasons in cowpea than in peanut.

Under WW treatment, peanut and cowpea pod yields were quite stable across seasons (Fig. 3a). Under WW conditions, the peanut pod yield was higher than cowpea pod yield in the two seasons. Under WS conditions, the pod yield of peanut was similar to that of cowpea in the rainy season, but was one-third that of cowpea in the post-rainy season $\left(1.5 v .4 .7 \mathrm{~g} \mathrm{plant}^{-1}\right)$ (Tables 2, 3). The differences in pod yield between seasons under WS were higher in peanut than in cowpea, suggesting greater pod yield stability in cowpea across seasons than in peanut. Under WW treatment, total haulm biomass production was higher in peanut than in cowpea in the two seasons. Under WW conditions, the difference between peanut and cowpea was up to 16 and $12 \mathrm{~g} \mathrm{plant}^{-1}$, respectively, in the post-rainy and rainy season, respectively. Under WS conditions, haulm dry weight
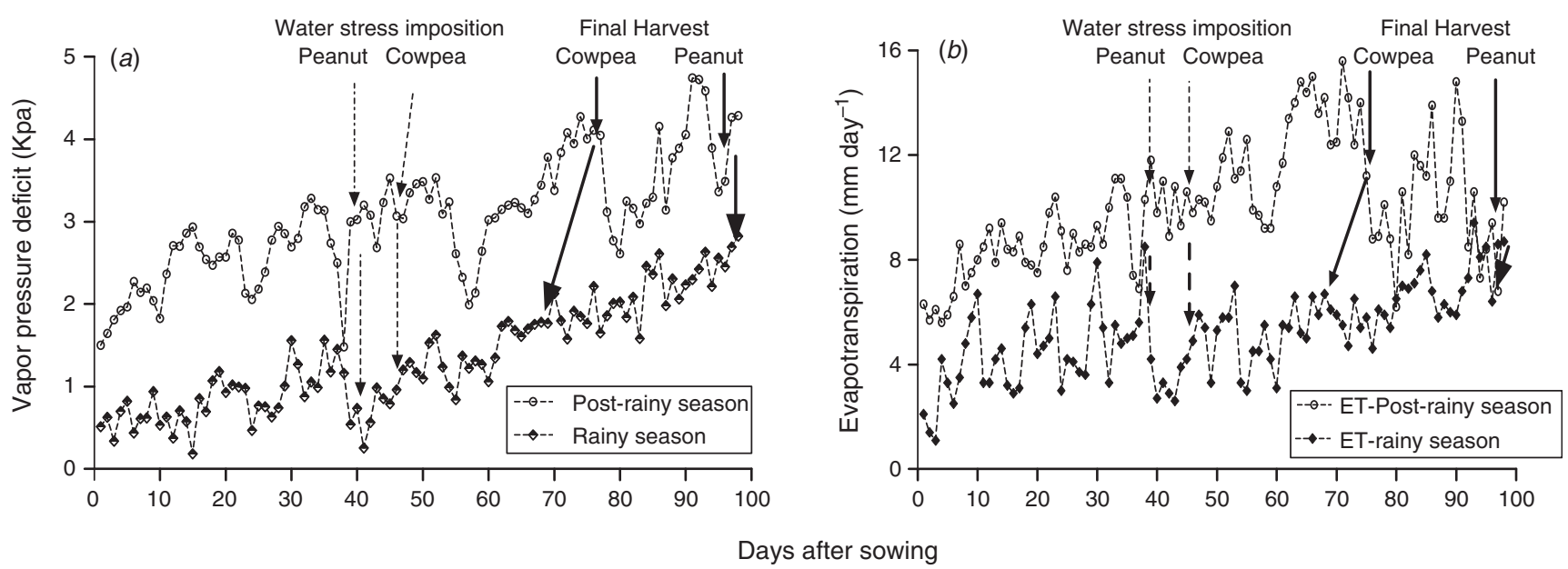

Fig. 1. (a) Vapour pressure deficit and (b) evapotranspiration during the experimental period in the post-rainy season and rainy seasons.

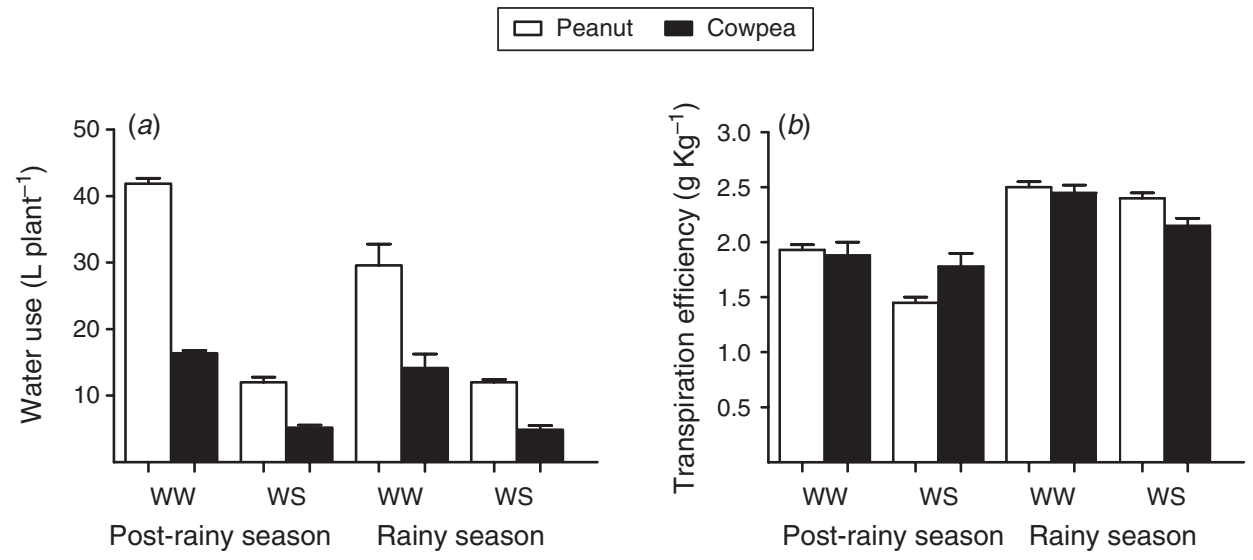

Fig. 2. (a) Water use and (b) transpiration efficiency in cowpea and peanut under well-watered (WW) and water-stress (WS) conditions in the post-rainy and rainy seasons. Data are means of the means for each genotype-treatment combination ( \pm s.e.d.). Each genotypic mean was calculated before that from the five replicates per genotype-treatment combinations. 
was similar between crops in the post-rainy season but higher in peanut in the rainy season (Fig. $3 b$ ). Under WW treatment, HI was higher in peanut than in cowpea in both seasons (Fig. 3c). Under WS treatment, the HI of peanut was higher than in cowpea in the rainy season, but below that of cowpea in the post-rainy season (Fig. 3c). Therefore, the HI of cowpea was more stable across seasons than that of peanut, where it showed large seasonal fluctuations under WS.

In summary, there were species differences in yield and yield components. Cowpea appeared better adapted to the high evaporative demand of the post-rainy season, especially under WS conditions, because it showed more stability in several indices across season (HI, TE, yield). As expected, peanut had
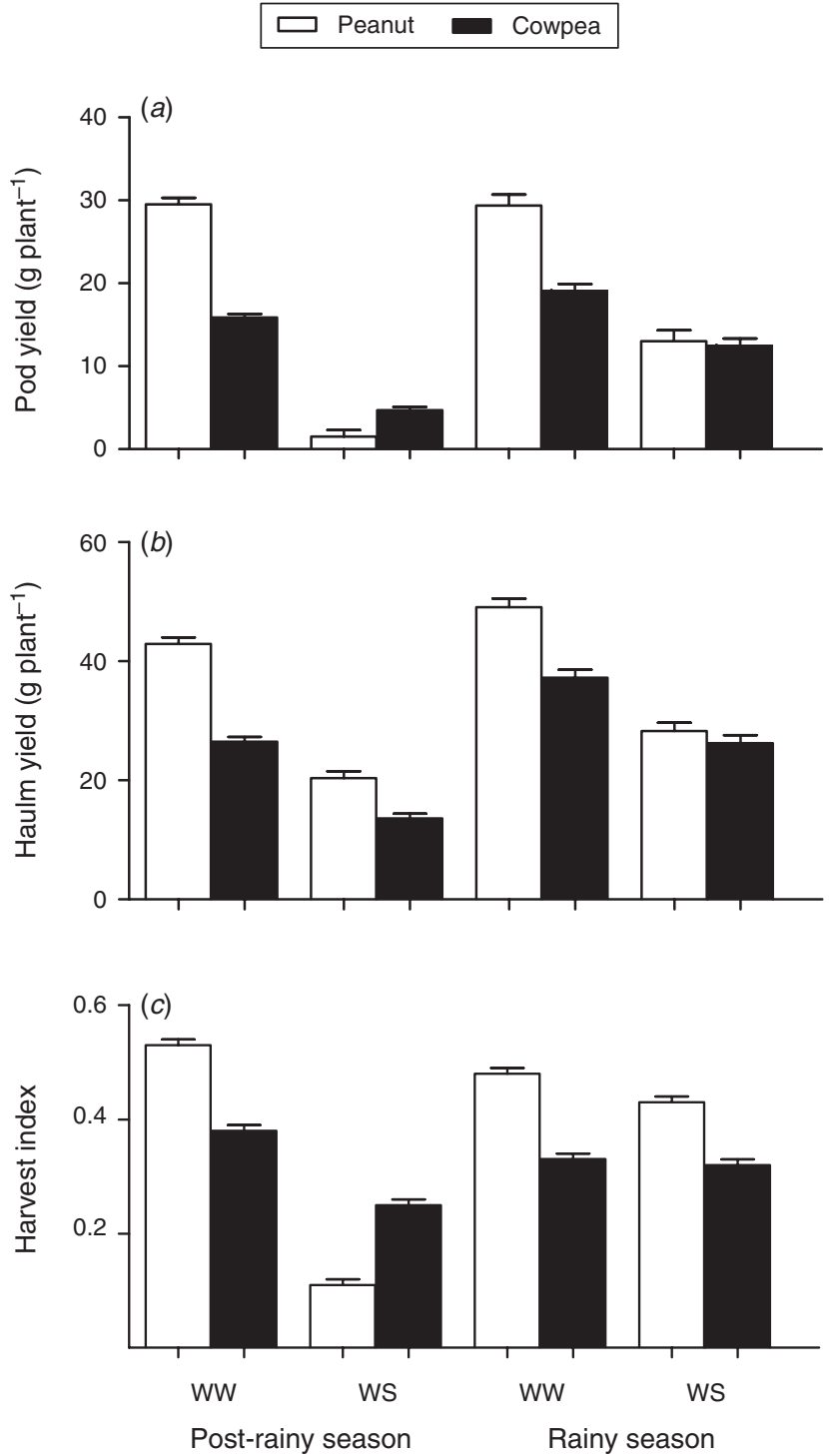

Fig. 3. (a) Pod yield, $(b)$ haulm yield and $(c)$ harvest index, in cowpea and peanut under well-watered (WW) and water-stress (WS) conditions in the post-rainy and rainy seasons. Data are means of the means for each genotype-treatment combinations $( \pm$ s.e.d.). Each genotypic mean was calculated before that from the five replicates per genotype-treatment combinations. higher yield potential but it was more affected by WS conditions, especially in the post-rainy season.

\section{Within-species differences in traits}

\section{Genotypic variation in water use}

Under WW conditions, no significant genotypic variation in total plant water use was observed for peanut in the rainy season, whereas genotypic differences were significant in the post-rainy season. For cowpea, the genotypic variation in water use was significant in both the rainy and post-rainy seasons. The range of variation in the post-rainy season was similar for both crops, that is, $\sim 2$-fold range (Tables 2 and 3). Peanut and cowpea showed strong genotypic variation for water use across environments (seasons) $(P<0.001)$. There was also a significant $(P=0.026)$ $\mathrm{G} \times \mathrm{S}$ interaction for cowpea, although the variance had a lower magnitude than the variance of genotypic effects (Table 3 ). There was no significant $\mathrm{G} \times \mathrm{S}$ interaction for peanut. Under WS conditions, no genotypic variation was observed in the two seasons for peanut, and for cowpea, it was significant in the rainy season only. The season effect was not significant for peanut or cowpea under WS.

\section{Genotypic variation in water extraction under stress}

Water extraction was evaluated in the WS treatment by subtracting the final tube weight from the tube weight at field capacity. In peanut and cowpea, genotypic variation was found in the two seasons. Peanut extracted more water than cowpea under WS conditions in the two seasons (Fig. $4 a, b$ ). In the post-rainy season, peanut extracted 7.3 $\mathrm{L} \mathrm{plant}^{-1}$ of water (on average). The range of variation was from $6.1 \mathrm{~L} \mathrm{plant}^{-1}$ for ICG 15287 to $8.3 \mathrm{~L}$ plant $^{-1}$ for ICG 97183 (Fig. 4a). In cowpea, average water extraction was $4.8 \mathrm{~L}_{\text {plant }}^{-1}$, from $3.3 \mathrm{~L}_{\text {plant }}{ }^{-1}$ for IT84S2049 to $6.6 \mathrm{~L} \mathrm{plant}^{-1}$ for IT82E-18 (Fig. 4b, Table 3). During the rainy season, peanut extracted, on average, $7.4 \mathrm{~L} \mathrm{plant}^{-1}$ of water, from 6.8 $\mathrm{L} \mathrm{plant}^{-1}$ for ICGV 01232 to $7.8 \mathrm{~L} \mathrm{plant}^{-1}$ for ICG 8751. Cowpea water extraction averaged 6.7 $\mathrm{L} \mathrm{plant}^{-1}$ and ranged from 3.7 $\mathrm{L}_{\text {plant }}{ }^{-1}$ for IT82E-18 to $7.5 \mathrm{~L} \mathrm{plant}^{-1}$ for IT93K-503-1. A G $\times$ S interaction $(P=0.006)$ was found in peanut, although the magnitude of genotypic variance $(P=0.004)$ was higher than the interaction effect. $\mathrm{A} \mathrm{G} \times \mathrm{S}$ interaction $(P<0.001)$ was also found in cowpea, but in this case, the magnitude of the genotypic variance was less than the interaction effect.

\section{Genotypic variation in transpiration efficiency}

Under WW conditions, genotypic variation for TE was not significant in peanut in either the rainy or post-rainy season, whereas it was significant in cowpea. The range of variation for TE in cowpea was larger (almost 50\%) in the rainy season than in the post-rainy season (Tables 2 and 3). IT97K-556-6 showed the highest TE $\left(3.03 \mathrm{~g} \mathrm{~kg}^{-1}\right)$ and IT82E-18 the lowest TE $(1.74 \mathrm{~g}$ $\mathrm{kg}^{-1}$ ). Under WW conditions, there was a significant season effect on TE in peanut and cowpea, but no $\mathrm{G} \times \mathrm{S}$ effect for the two crops. Under WS conditions, genotypic variation was observed only in peanut in the post-rainy season (Table 2), where TE ranged between $1.13 \mathrm{~g} \mathrm{~kg}^{-1}$ (ICGS 44) and $2.02 \mathrm{~g} \mathrm{~kg}^{-1}$ (ICGV 01232). There was no TE difference in the rainy season for both crops. Under WS treatment, a significant season effect was found but no significant $\mathrm{G} \times \mathrm{S}$ interaction. 
Table 2. Peanut water use (WU), transpiration efficiency (TE), harvest index (HI), and pod and haulm yield the in post-rainy and rainy seasons under well-watered (WW) and water-stress (WS) conditions, and genotypic (G), season (S) and genotype $\times$ season $(\mathrm{G} \times \mathrm{S})$ effects

$$
\text { n.s., Not significant at } P=0.05
$$

\begin{tabular}{|c|c|c|c|c|c|c|c|c|c|c|}
\hline \multirow[t]{2}{*}{ Genotypes } & \multicolumn{2}{|c|}{$\begin{array}{c}\text { WU } \\
\left(\mathrm{L} \mathrm{plant}^{-1}\right)\end{array}$} & \multicolumn{2}{|c|}{$\begin{array}{c}\mathrm{TE} \\
\left(\mathrm{g} \mathrm{kg}^{-1}\right)\end{array}$} & \multicolumn{2}{|c|}{$\mathrm{HI}$} & \multicolumn{2}{|c|}{$\begin{array}{l}\text { Pod yield } \\
\left(\text { g plant }^{-1}\right)\end{array}$} & \multicolumn{2}{|c|}{$\begin{array}{l}\text { Haulm yield } \\
(\mathrm{g} \text { plant }\end{array}$} \\
\hline & WW & WS & WW & WS & WW & WS & WW & WS & WW & WS \\
\hline ICG 97183 & 44.2 & 13.3 & 2.06 & 1.3 & 0.55 & 0.11 & 33.1 & 1.4 & 44.1 & 18.6 \\
\hline ICGV 97182 & 42.5 & 13 & 1.96 & 1.39 & 0.43 & 0.09 & 27.3 & 1.4 & 53.9 & 21.9 \\
\hline ICGV 02266 & 44.1 & 12.4 & 1.91 & 1.18 & 0.47 & 0.08 & 30.5 & 0.8 & 53.5 & 17.9 \\
\hline ICGV 02189 & 46.2 & 13.1 & 1.8 & 1.31 & 0.44 & 0.08 & 26.3 & 1 & 57.1 & 18.9 \\
\hline ICG 12697 & 47.2 & 12.5 & 2.03 & 1.19 & 0.56 & 0.07 & 35 & 0.8 & 44.9 & 16.6 \\
\hline ICG 8751 & 44.9 & 11.1 & 1.77 & 1.74 & 0.44 & 0.19 & 23.3 & 3 & 49.2 & 20.9 \\
\hline ICGV 01232 & 37.6 & 10.4 & 2.17 & 2.02 & 0.61 & 0.17 & 32.4 & 2.9 & 34.9 & 24.6 \\
\hline ICGV 91114 & 43.7 & 11.3 & 1.94 & 1.19 & 0.54 & 0.08 & 30.6 & 0.8 & 42.8 & 18.4 \\
\hline $55-437$ & 47.7 & 12.2 & 2.12 & 1.42 & 0.58 & 0.09 & 37.2 & 1.2 & 45.1 & 20.5 \\
\hline ICGS 44 & 34.6 & 12.1 & 1.76 & 1.13 & 0.6 & 0.08 & 24.6 & 1 & 27.2 & 20.1 \\
\hline ICG 15287 & 43.3 & 11 & 1.98 & 1.39 & 0.56 & 0.08 & 31.5 & 1.2 & 40.1 & 22.5 \\
\hline ICG1834 & 38.9 & 12.3 & 1.67 & 1.16 & 0.55 & 0.16 & 30.5 & 2 & 38.7 & 17.5 \\
\hline FLEUR 11 & 36.1 & 11 & 1.97 & 1.58 & 0.57 & 0.08 & 29.4 & 1.3 & 36.9 & 23.2 \\
\hline ICGV 99001 & 25.9 & 11.6 & 1.77 & 1.79 & 0.51 & 0.08 & 18.8 & 1 & 26.6 & 19.9 \\
\hline$F$-prob. & 0.002 & 0.052 & n.s. & 0.05 & 0.003 & $<0.001$ & 0.002 & $<0.001$ & $<0.001$ & n.s. \\
\hline$F$-value & 2.72 & 1.76 & 1.25 & 1.8 & 2.69 & 6.19 & 2.86 & 8.71 & 3.33 & 1.28 \\
\hline 1.s.d. & 10.1 & 1.8 & 0.41 & 0.5 & 0.11 & 0.05 & 9.67 & 0.7 & 12.8 & 5.5 \\
\hline Mean & 41.9 & 12 & 1.9 & 1.5 & 0.5 & 0.1 & 29.3 & 1.5 & 42.9 & 20.5 \\
\hline Max. & 51.4 & 13.3 & 2.17 & 2 & 0.61 & 0.2 & 40.8 & 3 & 57.1 & 24.6 \\
\hline Min. & 25.9 & 10.4 & 1.54 & 1.1 & 0.37 & 0.05 & 18.8 & 0.7 & 26.6 & 16.6 \\
\hline \multicolumn{11}{|c|}{ Rainy season } \\
\hline ICGV 91114 & 25.9 & 12 & 2.75 & 2.24 & 0.44 & 0.42 & 23.2 & 12.1 & 49.9 & 27.5 \\
\hline $55-437$ & 31.1 & 12 & 2.68 & 2.35 & 0.52 & 0.44 & 34.1 & 12.7 & 60.4 & 26.4 \\
\hline ICGS 44 & 23.9 & 11.3 & 2.53 & 2.36 & 0.56 & 0.49 & 29.9 & 14.6 & 36.2 & 21.1 \\
\hline ICGV 00350 & 27.4 & 11.4 & 2.96 & 2.71 & 0.57 & 0.51 & 38.2 & 16.6 & 41 & 27 \\
\hline ICG 4750 & 36.5 & 11.9 & 2.4 & 2.61 & 0.45 & 0.42 & 31.9 & 15.9 & 61.8 & 35.2 \\
\hline ICG 3584 & 38.5 & 12.1 & 2.34 & 2.45 & 0.52 & 0.43 & 36.5 & 13.2 & 52.9 & 28.7 \\
\hline TMV2 & 28.2 & 12 & 2.41 & 2.51 & 0.53 & 0.4 & 34 & 12.5 & 44.9 & 30.5 \\
\hline JL 24 & 28.4 & 11.8 & 2.53 & 2.48 & 0.5 & 0.47 & 29 & 14.7 & 46.5 & 29.3 \\
\hline ICG 15287 & 29.6 & 12.2 & 2.72 & 2.32 & 0.53 & 0.46 & 34.6 & 13 & 48.7 & 25.9 \\
\hline ICG1834 & 23.9 & 11.6 & 2.23 & 2.06 & 0.38 & 0.44 & 17.6 & 10.5 & 42.1 & 21.9 \\
\hline FLEUR 11 & 21.3 & 11.9 & 2.45 & 2.15 & 0.45 & 0.47 & 20.5 & 12.2 & 39.2 & 25.8 \\
\hline ICGV 99001 & 29 & 12.3 & 2.45 & 2.27 & 0.36 & 0.4 & 20.3 & 11.2 & 57.6 & 27.4 \\
\hline$F$-prob. & n.s. & n.s. & n.s. & n.s. & 0.022 & $<0.001$ & n.s. & 0.011 & 0.011 & 0.032 \\
\hline$F$-value & 1.29 & 1.04 & 1.21 & 1.52 & 2.05 & 3.11 & 1.45 & 2.25 & 2.21 & 1.91 \\
\hline 1.s.d. & 12.6 & 0.9 & 0.53 & 0.4 & 0.14 & 0.1 & 15.8 & 3.9 & 16.5 & 7.7 \\
\hline Mean & 29.6 & 11.9 & 2.5 & 2.4 & 0.48 & 0.43 & 29.4 & 12.9 & 49 & 28.3 \\
\hline Max. & 38.7 & 12.5 & 2.96 & 2.72 & 0.6 & 0.51 & 39.6 & 16.6 & 66.9 & 35.2 \\
\hline Min. & 21.3 & 11.3 & 2.17 & 2.06 & 0.36 & 0.26 & 17.6 & 7.5 & 35.1 & 21.1 \\
\hline G $F$-value & 2.73 & 1.85 & 1.6 & 1.75 & 3.49 & 2.68 & 2.74 & 2.83 & 3 & 1.6 \\
\hline G $F$-prob. & $<0.001$ & 0.025 & n.s. & 0.04 & $<0.001$ & $<0.001$ & $<0.001$ & $<0.001$ & $<0.001$ & n.s. \\
\hline
\end{tabular}


Table 2. (continued)

\begin{tabular}{|c|c|c|c|c|c|c|c|c|c|c|}
\hline \multirow[t]{2}{*}{ Genotypes } & \multicolumn{2}{|c|}{$\begin{array}{c}\text { WU } \\
\left(\mathrm{L} \text { plant }^{-1}\right)\end{array}$} & \multicolumn{2}{|c|}{$\begin{array}{c}\mathrm{TE} \\
\left(\mathrm{g} \mathrm{kg}^{-1}\right)\end{array}$} & \multicolumn{2}{|c|}{$\mathrm{HI}$} & \multicolumn{2}{|c|}{$\begin{array}{l}\text { Pod yield } \\
\left(\mathrm{g} \mathrm{plant}^{-1}\right)\end{array}$} & \multicolumn{2}{|c|}{$\begin{array}{l}\text { Haulm yield } \\
\left.\text { (g plant }^{-1}\right)\end{array}$} \\
\hline & WW & WS & WW & WS & WW & WS & WW & WS & WW & WS \\
\hline $\mathrm{S} F$-value & 93.75 & 0.14 & 116 & 317 & 8.2 & 1656 & 0.02 & 1292 & 15 & 113 \\
\hline $\mathrm{S} F$-prob. & $<0.001$ & n.s. & $<0.001$ & $<0.001$ & 0.01 & $<0.001$ & n.s. & $<0.001$ & $<0.001$ & $<0.001$ \\
\hline $\mathrm{G} \times \mathrm{S} F$-value & 1.03 & 1.59 & 0.64 & 1.63 & 1.71 & 5.43 & 1.1 & 2.57 & 2.3 & 1.9 \\
\hline $\mathrm{G} \times \mathrm{S} F$-prob & n.s. & n.s. & n.s. & n.s. & 0.05 & $<0.001$ & n.s. & 0.001 & 0.003 & 0.022 \\
\hline
\end{tabular}

Table 3. Cowpea water use (WU), transpiration efficiency (TE), harvest index (HI), and pod and haulm yield in the post-rainy and rainy seasons under well-watered (WW) and water-stress (WS) conditions, and genotypic (G), season (S) and genotype $\times$ season $(\mathrm{G} \times \mathrm{S})$ effects n.s., Not significant at $P=0.05$

\begin{tabular}{|c|c|c|c|c|c|c|c|c|c|c|}
\hline \multirow[t]{2}{*}{ Genotypes } & \multicolumn{2}{|c|}{$\begin{array}{c}\text { WU } \\
\left(\text { L plant }^{-1}\right)\end{array}$} & \multicolumn{2}{|c|}{$\begin{array}{c}\mathrm{TE} \\
\left(\mathrm{g} \mathrm{kg}^{-1}\right)\end{array}$} & \multicolumn{2}{|c|}{$\mathrm{HI}$} & \multicolumn{2}{|c|}{$\begin{array}{l}\text { Pod yield } \\
\left(\text { g plant }^{-1}\right)\end{array}$} & \multicolumn{2}{|c|}{$\begin{array}{l}\text { Haulm yield } \\
\left.\text { (g plant }^{-1}\right)\end{array}$} \\
\hline & WW & WS & WW & WS & WW & WS & WW & WS & WW & WS \\
\hline \multicolumn{11}{|c|}{ Post-rainy season } \\
\hline IT84S-2049 & 12.4 & 4.7 & 1.86 & 2.04 & 0.35 & 0.34 & 13.8 & 5.8 & 24.4 & 9.9 \\
\hline IT85F-3139 & 18.9 & 4.8 & 2.16 & 2.45 & 0.4 & 0.27 & 19.6 & 5.6 & 29.6 & 14 \\
\hline IT93K-693-2 & 15 & 5.8 & 2.03 & 1.69 & 0.47 & 0.33 & 18.6 & 6.2 & 21 & 12.3 \\
\hline IT98K-1105-5 & 15.1 & 5.5 & 2.38 & 1.41 & 0.33 & 0.24 & 14.3 & 4.4 & 30 & 13.6 \\
\hline Mouride & 13.7 & 6 & 1.53 & 1.84 & 0.38 & 0.27 & 13.6 & 7.9 & 21.4 & 14.3 \\
\hline IT93K-503-1 & 18.1 & 5.6 & 2.2 & 2.08 & 0.46 & 0.25 & 25 & 5.3 & 29.7 & 16.5 \\
\hline IT96D-610 & 15 & 5.2 & 2.03 & 1.02 & 0.4 & 0.24 & 16 & 3.8 & 24.3 & 11.8 \\
\hline IT98K-428-3 & 20.1 & 5.4 & 2.14 & 1.33 & 0.34 & 0.28 & 17.5 & 5.4 & 33.4 & 13.7 \\
\hline IT99K-124-5 & 18.5 & 5.5 & 2.22 & 2.24 & 0.4 & 0.34 & 19.2 & 7.2 & 28.4 & 14.1 \\
\hline Suvita 2 & 14.2 & 4.5 & 1.68 & 1.47 & 0.39 & 0.33 & 13.7 & 5.3 & 22.4 & 10.7 \\
\hline Bambey 21 & 15.3 & 4.8 & 1.55 & 1.84 & 0.28 & 0.31 & 9.9 & 6 & 26.1 & 11.9 \\
\hline $\mathrm{UC}-\mathrm{CB} 46$ & 12.6 & 4.6 & 2.14 & 1.12 & 0.39 & 0.24 & 14.4 & 4.4 & 22.7 & 13 \\
\hline IT82E-18 & 12.4 & 6 & 1.66 & 1.87 & 0.41 & 0.41 & 12.9 & 7.6 & 18.4 & 11 \\
\hline IT84S-2246 & 18.2 & 4.5 & 1.85 & 1.42 & 0.37 & 0.14 & 16.3 & 2.2 & 28.4 & 12.8 \\
\hline IT93K-93-10 & 14 & 5.4 & 1.37 & 2.2 & 0.46 & 0.4 & 17 & 9.3 & 17.6 & 12.2 \\
\hline IT83D-442 & 21.5 & 4 & 1.77 & 1.92 & 0.32 & - & 18.1 & 0 & 34.3 & 14.9 \\
\hline IT90K-284-2 & 21.5 & 4.9 & 2.23 & 3.02 & 0.27 & 0.02 & 13.7 & 0.2 & 38.7 & 19.9 \\
\hline IT95K-1095-4 & 19.9 & 6.4 & 1.64 & 1.12 & 0.39 & 0.14 & 18.9 & 3.2 & 28.9 & 13.2 \\
\hline IT97K-556-6 & 14.2 & 5.2 & 1.69 & 2.49 & 0.33 & 0.23 & 10.3 & 5 & 24.3 & 17.5 \\
\hline KVX-525 & 17.5 & 5.2 & 1.54 & 0.98 & 0.36 & 0.01 & 14.5 & 0 & 27.2 & 16.1 \\
\hline$F$-prob. & $<0.001$ & n.s. & 0.05 & n.s. & $<0.001$ & $<0.001$ & $<0.001$ & $<0.001$ & $<0.001$ & $<0.001$ \\
\hline$F$-value & 3 & 0.9 & 1.78 & 1.3 & 3.28 & 8.1 & 4.86 & 6.6 & 3.03 & 3.6 \\
\hline 1.s.d. & 5 & 1.8 & 0.64 & 1.37 & 0.09 & 0.12 & 4.5 & 2.9 & 8.8 & 3.7 \\
\hline Mean & 16.4 & 5.2 & 1.9 & 1.8 & 0.4 & 0.2 & 15.9 & 4.7 & 26.6 & 13.7 \\
\hline Max. & 21.5 & 6.4 & 2.38 & 3.02 & 0.47 & 0.4 & 25 & 9.3 & 38.7 & 19.9 \\
\hline Min. & 12.4 & 4 & 1.37 & 0.98 & 0.27 & 0.02 & 9.9 & 0 & 17.6 & 9.9 \\
\hline \multicolumn{11}{|c|}{ Rainy season } \\
\hline IT84S-2049 & 9.5 & 4.6 & 2.5 & 2.29 & 0.33 & 0.24 & 14.5 & 11.1 & 29 & 29.9 \\
\hline IT85F-3139 & 15.4 & 5.5 & 2.68 & 2.46 & 0.37 & 0.31 & 24.6 & 14.2 & 43.3 & 30.6 \\
\hline IT93K-693-2 & 13.9 & 5.1 & 2.22 & 2.29 & 0.29 & 0.27 & 13.7 & 8.4 & 28.2 & 25.6 \\
\hline IT98K-1105-5 & 10.1 & 5 & 2.34 & 2.2 & 0.23 & 0.33 & 9 & 15.2 & 31.1 & 29.7 \\
\hline Mouride & 12.7 & 4.8 & 2.22 & 2.13 & 0.3 & 0.32 & 16.2 & 12.1 & 38.1 & 25.6 \\
\hline IT93K-503-1 & 20.2 & 5.5 & 2.25 & 1.81 & 0.35 & 0.18 & 26.1 & 5.7 & 41.5 & 26.9 \\
\hline IT96D-610 & 18.2 & 4.8 & 2.93 & 2.39 & 0.36 & 0.39 & 26.5 & 16.9 & 46.4 & 25.8 \\
\hline IT98K-428-3 & 14.4 & 5.3 & 2.57 & 1.99 & 0.37 & 0.45 & 20.2 & 18.7 & 33.5 & 20.6 \\
\hline IT99K-124-5 & 16 & 4.5 & 2.46 & 1.89 & 0.38 & 0.33 & 27.2 & 13.8 & 41.3 & 23 \\
\hline Suvita 2 & 16.2 & 5 & 2.44 & 2.26 & 0.3 & 0.39 & 20.1 & 16.8 & 45.8 & 25.8 \\
\hline Bambey 21 & 12.5 & 5.5 & 2.72 & 2.28 & 0.31 & 0.24 & 16.3 & 10 & 35.9 & 31.4 \\
\hline UC-CB 46 & 11.2 & 4.8 & 2.22 & 2.53 & 0.36 & 0.34 & 15.4 & 16.2 & 27.1 & 31.6 \\
\hline IT82E-18 & 6.7 & 3.9 & 1.74 & 2.36 & 0.28 & 0.34 & 9.1 & 13.5 & 19.1 & 26.4 \\
\hline IT84S-2246 & 11.3 & 5.8 & 2.78 & 2.11 & 0.35 & 0.3 & 18.4 & 10 & 33.8 & 23.2 \\
\hline IT93K-93-10 & 12.8 & 4.5 & 2.19 & 2.41 & 0.35 & 0.42 & 18.6 & 19 & 34.1 & 26.8 \\
\hline IT83D-442 & 18.5 & 3.4 & 2.43 & 1.89 & 0.32 & 0.35 & 21.9 & 12.6 & 47.8 & 24.3 \\
\hline
\end{tabular}


Table 3. (continued)

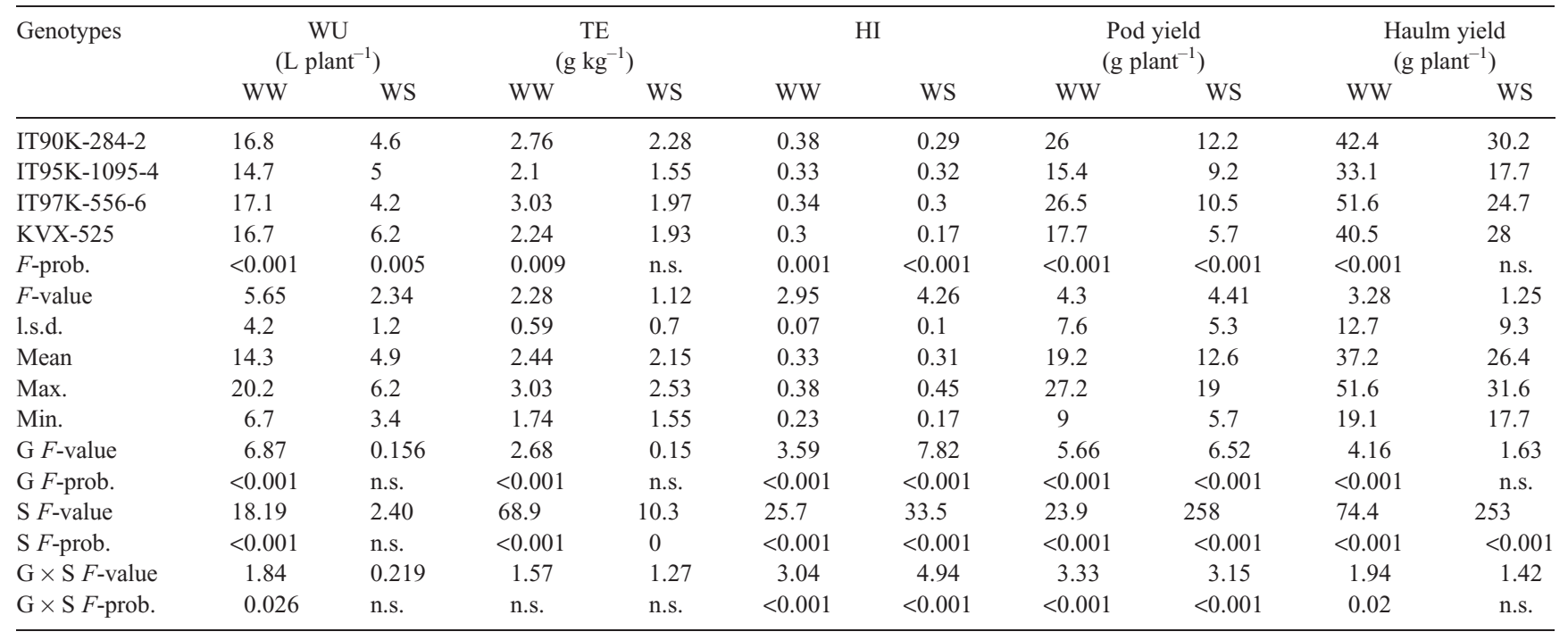

- Post-rainy $\nabla$ Rainy \Lsd Post-rainy $\quad$ Lsd Rainy
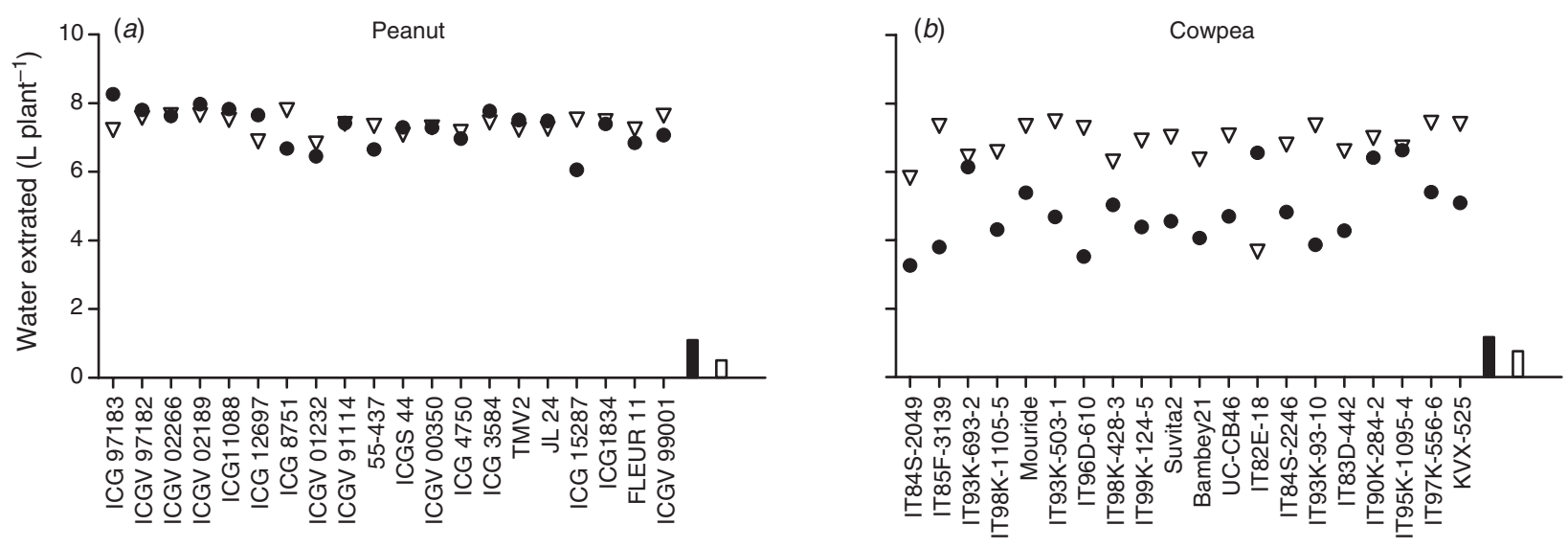

Genotypes

Fig. 4. Water extraction per plant in $(a)$ peanut and $(b)$ cowpea under stress conditions in the post-rainy and rainy seasons.

\section{Genotypic variation in harvest index}

Under WW conditions, in both peanut and cowpea there was genotypic variation for $\mathrm{HI}$ in both seasons (Tables 2 and $3)$. In the post-rainy season, $\mathrm{HI}$ in peanut ranged from 0.61 (ICGV 01232) to 0.37 (ICG 11088), and in cowpea from 0.47 (IT93K-693-2) to 0.27 (IT90K-284-2). In the rainy season, HI in peanut ranged from 0.6 (ICGV 01232) to 0.36 (ICGV 99001), and in cowpea from 0.38 (IT99K-124-5; IT90K-284-2) to 0.23 (IT98K-1105-5) (Tables 2 and 3). A significant $\mathrm{G} \times \mathrm{S}$ interaction was observed for $\mathrm{HI}$ in both cowpea and peanut under WW conditions, although the variance of the interaction was lower than the genotypic variance in both species (Tables 2 and 3). The two crops showed genotypic differences for $\mathrm{HI}$ in both seasons under WS conditions, although in the post-rainy season, HI was very low in both crops. The range of HI was $0.05-0.2$ in peanut and $0.02-0.4$ in cowpea. The $\mathrm{G} \times \mathrm{S}$ interaction under WS was significant for cowpea and peanut. In both crops, the season effect had a stronger influence than the genotypic variation.

\section{Genotypic variation in pod and haulm yield}

Under WW treatment, genotypic variation for pod yield was observed in the post-rainy season only for peanut, whereas in cowpea it was observed in the two seasons. In the post-rainy season, pod yield in peanut ranged from 18.8 to $40.8 \mathrm{~g} \mathrm{plant}^{-1}$ and in cowpea from 9.9 to $25 \mathrm{~g} \mathrm{plant}^{-1}$ (Tables 2 and 3 ). In the rainy season, pod yield in cowpea ranged from 9.0 to $27.2 \mathrm{~g} \mathrm{plant}^{-1}$, a range similar to the post-rainy season. Nevertheless, the $\mathrm{G} \times \mathrm{S}$ interaction for pod yield was significant only in cowpea. Under 
WS conditions, there was genotypic variation in both rainy and post-rainy seasons, and in both peanut and cowpea. In the post-rainy season, the pod yield range of variation was $0.7-3 \mathrm{~g}$ plant $^{-1}$ for peanut and $0-9.3 \mathrm{~g} \mathrm{plant}^{-1}$ for cowpea (Tables 2 and 3). Under WS treatment in the rainy season, pod yield in peanut varied from 7.5 to $16.6 \mathrm{~g} \mathrm{plant}^{-1}$ and in cowpea from 5.7 to $19 \mathrm{~g} \mathrm{plant}^{-1}$ (Tables 2 and 3). Under stress, a significant season effect and $\mathrm{G} \times \mathrm{S}$ interaction was observed in peanut and cowpea.

Under WW conditions, there was significant genotypic variation for haulm yield across crops and seasons (Tables 2 and 3). In the post-rainy season, haulm yield in peanut varied between 26.6 and $57.1 \mathrm{~g} \mathrm{plant}^{-1}$ and in cowpea between 17.6 and $38.7 \mathrm{~g} \mathrm{plant}^{-1}$. In the rainy season, the haulm yield in peanut ranged from $35.1 \mathrm{~g} \mathrm{plant}^{-1}$ (ICGV 97182) to $66.9 \mathrm{~g} \mathrm{plant}^{-1}$ (ICG 11088), whereas in cowpea it varied from $19.1 \mathrm{~g} \mathrm{plant}^{-1}$ (IT82E18) to 51.6 g plant $^{-1}$ (IT97K-556-6). There was significant $\mathrm{G} \times \mathrm{S}$ interaction for haulm biomass under WW conditions in peanut and cowpea; nevertheless, the season effect was stronger than the $\mathrm{G} \times \mathrm{S}$ interaction. Under WS treatment, in peanut there were no genotypic differences for haulm yield in the post-rainy season, whereas in cowpea there were significant differences, with haulm yield varying from 9.9 to $19.9 \mathrm{~g} \mathrm{plant}^{-1}$ in the post rainy season. In the rainy season, there was genotypic variation in peanut but not in cowpea. The haulm biomass ranged from 21.1 to $35.2 \mathrm{~g} \mathrm{plant}^{-1}$ $(P<0.05)$ for peanut and from 17.7 to $31.6 \mathrm{~g} \mathrm{plant}^{-1}$ (not significant) for cowpea. Under stress conditions, the $\mathrm{G} \times \mathrm{S}$ interaction was significant in peanut only and the magnitude was lower than season effect.

\section{Relationship between pod yield and component traits}

Under WW conditions, there were significant, high correlations between pod yield and HI in peanut in the post-rainy $\left(R^{2}=0.4\right)$ and rainy $\left(R^{2}=0.72\right)$ seasons (Fig. $\left.5 d\right)$. Cowpea pod yield was also correlated with $\mathrm{HI}\left(R^{2}=0.38\right.$ in the post-rainy and $R^{2}=0.53$ in the rainy season) (Fig. $5 c$ ). In both crops, HI influenced pods yield significantly, more so in the rainy season than the post-rainy season, especially in peanut under WW condition. The residuals of the relationship between pod yield and HI, i.e. those yield values below and above the regression equation between the pod yield and the HI, were calculated by subtracting the predicted pod yield from the observed values (Vadez et al. 2007b). These residuals represented the yield variation not accounted for by the HI, and these were plotted against TE and against the total plant water use. Under WW conditions in the post-rainy season, the residuals were highly correlated with water use $\left(R^{2}=0.74\right.$ and $R^{2}=0.62$ in peanut and cowpea, respectively), meaning that the part of the yield variation unexplained by HI was highly related to water use in the post-rainy season (Fig. $6 a, b$ ). These residual were also significantly related to water use in the rainy season, although the strength of the relationships was much lower than during the post-rainy season, and this correlation was higher in peanut $\left(R^{2}=0.46\right)$ than in cowpea $\left(R^{2}=0.17\right)$ (Fig. $\left.6 a, b\right)$. Under WW conditions in the post-rainy season, some correlation was also observed between residuals and TE in cowpea $\left(R^{2}=0.42\right)$ and peanut $\left(R^{2}=0.16\right)$ (Fig. $\left.6 c, d\right)$. In the rainy season, TE was also correlated to the residual yield in cowpea $\left(R^{2}=0.38\right)$ but not in peanut $\left(R^{2}=0.01\right)$ (Fig. $\left.6 c, d\right)$. In summary, under WW conditions, the residual yield not explained by HI was mostly

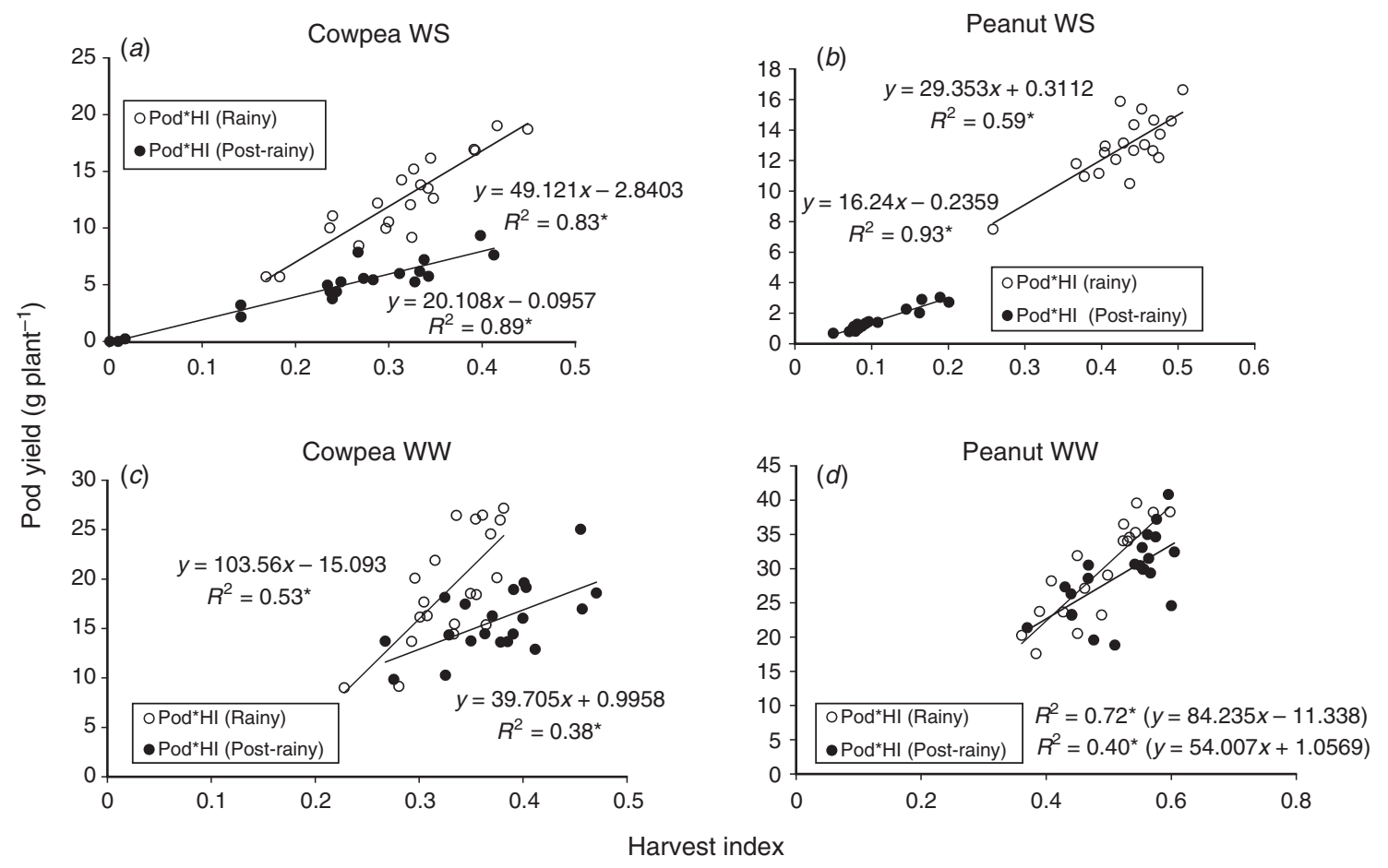

Fig. 5. Relationship between pod yield and harvest index in $(a, c)$ cowpea and $(b, d)$ peanut under water-stress (WS) and well-watered (WW) conditions in the post-rainy and rainy seasons. 


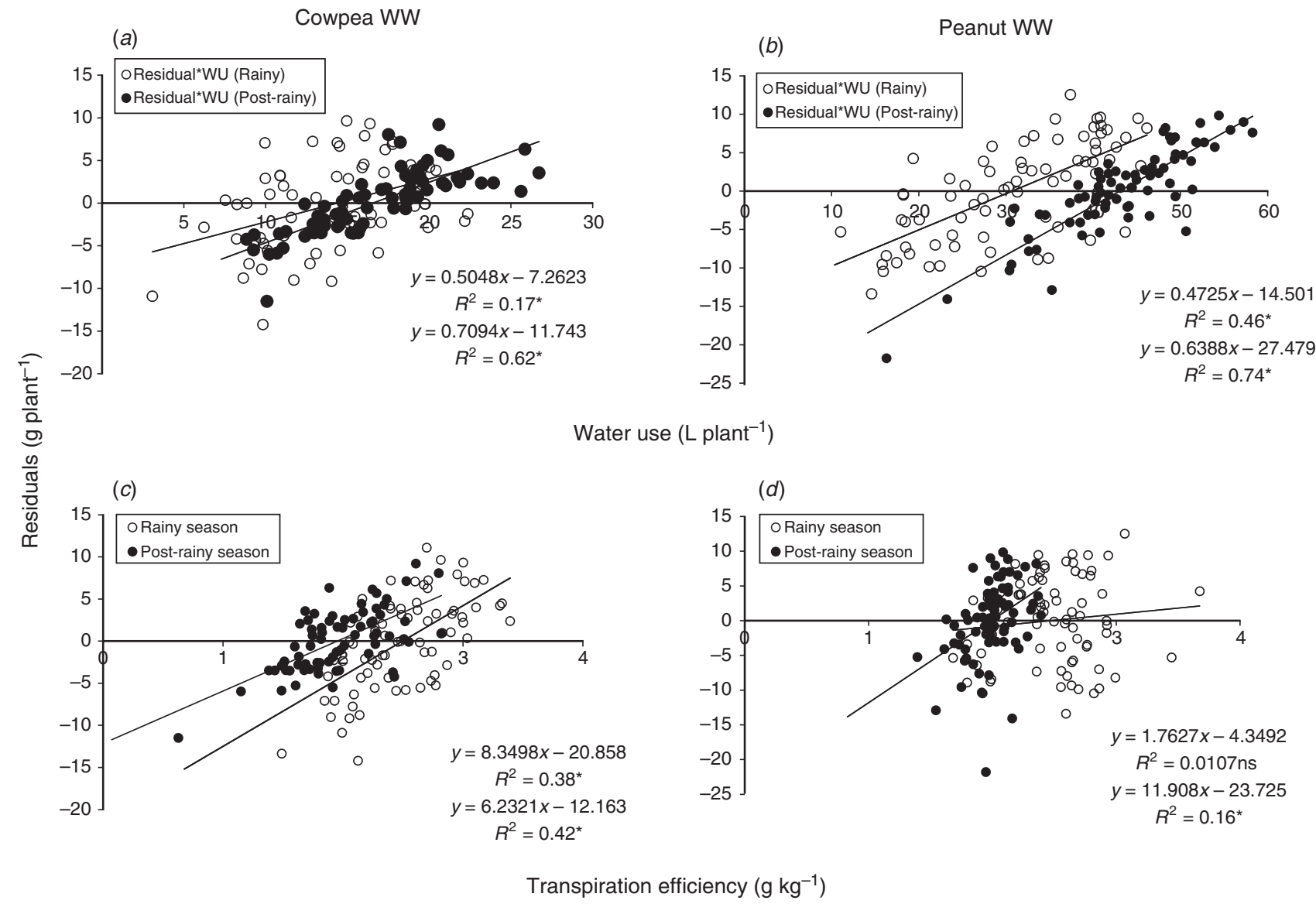

Fig. 6. Relationship between residual yields unexplained by HI and water use for $(a)$ cowpea and $(b)$ peanut; and relationship between residuals and transpiration efficiency for $(c)$ cowpea and $(d)$ peanut in the post-rainy and rainy seasons under well-watered (WW) conditions.

driven by water use, especially during the post-rainy season, and less so by TE. However, species-wise, TE had a much more important influence on these residual grain yields in cowpea than in peanut.

Under WS conditions in both seasons, pod yields were also strongly correlated with $\mathrm{HI}$ in both peanut and cowpea. In peanut, the correlation was stronger in the post-rainy $\left(R^{2}=0.93\right)$ than the rainy $\left(R^{2}=0.59\right)$ season, whereas in cowpea, the correlation was similar in both seasons (post-rainy, $R^{2}=0.89$; rainy, $R^{2}=0.83$ ) (Fig. 5a,b). Clearly, for both crops and seasons, the relationship of pods to HI was much stronger in the WS than the WW treatment. Residuals of yield calculated and plotted against TE and against total plant water use under WS showed a strong correlation with TE and very weak correlation with water use in the two crops. No significant correlation was found between water use and these residuals in the post-rainy and rainy seasons in peanut and cowpea (Fig. $7 a, b$ ). In the post-rainy season, the residual and TE were significantly correlated for peanut $\left(R^{2}=0.46\right)$ and cowpea $\left(R^{2}=0.38\right)$. The correlation was also significant in the rainy season in peanut $\left(R^{2}=0.71\right)$ and in cowpea $\left(R^{2}=0.74\right)($ Fig. $7 c, d)$. The slopes of the relationships were also higher in the rainy than the post-rainy season in both crops. In summary, under WS conditions, TE was a predominant factor explaining the yield residuals not explained by HI, more so in the rainy than the post-rainy season, whereas WU had no influence. Also the decrease in pod yield, haulm yield and $\mathrm{HI}$ caused by water stress were larger in the post-rainy than in the rainy season (see Supplementary Material Fig. 1 as available on the journal's website).

\section{Discussion}

Peanut and cowpea water requirements under well-watered and water-stress conditions were higher in the post-rainy than the rainy season. Cowpea used half the water of peanut, indicating large differences in water requirement between the two crops. Peanut and cowpea yield decreased because of drought in both seasons but the effect was less in cowpea, suggesting that pod yield in cowpea was more stable across seasons. The significant correlation between residual pod yield and TE suggests that TE was a good selection criterion for drought stress in peanut and cowpea. The large variation in water use across seasons in peanut while water use was more similar in cowpea also suggests that cowpea had tighter stomatal control than peanut in the season with high evaporative demand. For both peanut and cowpea, five varieties had high yield under drought across the seasons. Several genotypes with either high TE or high water extraction under WS conditions are also reported as tolerant to water deficit, for instance ICG 97183 or ICG 8751 in peanut and Mouride in cowpea for high water extraction, ICGV 11088 and ICGV 01232 


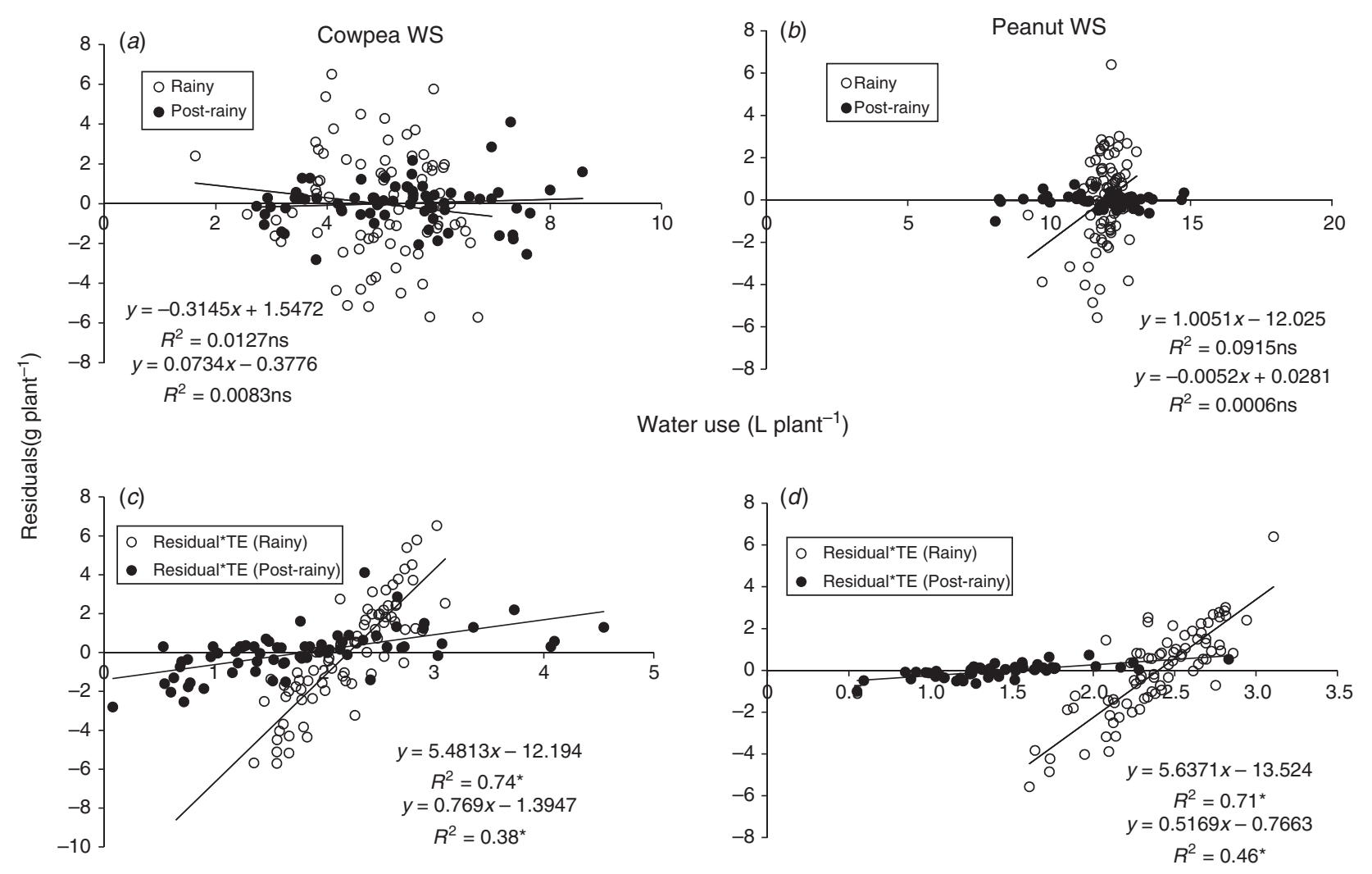

Transpiration efficiency $\left(\mathrm{g} \mathrm{kg}^{-1}\right)$

Fig. 7. Relationship between residual yields unexplained by HI and water use for $(a)$ cowpea and $(b)$ peanut; and relationship between residuals and transpiration efficiency for $(c)$ cowpea and $(d)$ peanut in the post-rainy and rainy seasons under water-stress (WS) conditions.

in peanut for high TE. Evaluation of varieties in the lysimeters was of agronomic relevance. At a planting density of 16 tubes $\mathrm{m}^{-2}$, a mean pod yield in peanut of $30 \mathrm{~g} \mathrm{plant}^{-1}$ (WW, post-rainy season) could be extrapolated to a yield of $480 \mathrm{~g} \mathrm{~m}^{-2}\left(4.8 \mathrm{tha}^{-1}\right)$, whereas in cowpea, a mean pod yield of $16 \mathrm{~g} \mathrm{plant}^{-1}$ (WW, post-rainy season) could be extrapolated to a yield of $260 \mathrm{~g} \mathrm{~m}^{-2}\left(2.6 \mathrm{t} \mathrm{ha}^{-1}\right)$, well in line with reported yields in the field in the region (Hamidou et al. 2012; Belko et al. 2013).

\section{Differences between species}

The species difference in yield largely depended water regime. Peanut had a clear advantage over cowpea under WW conditions, especially in the rainy season, but cowpea had either a similar or a higher yield under WS conditions. Rainy conditions could alleviate the impact of WS on HI in cowpea but not in peanut. In addition, under WS conditions, pod yield and $\mathrm{HI}$ in cowpea were more stable across seasons, whereas large fluctuation was found in peanut, showing that cowpea was more resilient under WS conditions than peanut. This could also relate to the fact that TE values were more stable across season in cowpea than in peanut, perhaps in part from a better capacity to deal with the high evaporative demand of the post-rainy season. These differences in TE stability may also be related to the differences in water stress regimes imposed on each of these crops. This ability of cowpea to tolerate drought probably relates to both an intrinsic adaptive strategy and a short reproductive period (25-35 days from flowering to pod maturity) (Pandey et al.
1987; Nyakatawa and Kamba 1996; Belko et al. 2014) compared with peanut (69-88days) (Boote 1982; Pandey et al. 1987; Ntare et al. 2008). Because of a short reproductive period (flowering to pod maturity), when exposed to terminal drought, water remaining in the tubes would be sufficient to complete pod maturation in cowpea. Although the decrease in water use under stress was almost the same in both crops and seasons, peanut showed larger pod yield and HI decreases under WS than cowpea. The intermittent stress applied in peanut was, in particular, severe in the post-rainy season and had a strong repercussion on HI. Our results also showed more reduction of yield and yield components than previous findings (Songsri et al. 2008; Ratnakumar and Vadez 2011; Hamidou et al. 2013). The fact that HI did not decrease under WS in the rainy season, whereas it did in the post-rainy season, and more so in peanut than in cowpea, suggests that the WS conditions might have affected specifically the reproductive success in the post-rainy season, and then that reproduction in peanut would have been more sensitive than in cowpea. That could also be explained in part by additional stress due to heat. Heat stress combined with drought has a more drastic effect on plant growth and yield than drought alone (Ferris et al. 1998; Prasad et al. 2000; Lobell et al. 2011; Cairns et al. 2012; Hamidou et al. 2013).

\section{Importance of TE in the determination of crop yield}

The residual yields unexplained by HI were highly correlated with TE in peanut and cowpea under stress conditions. This 
indicates that TE was an important explanatory component of yield under WS conditions and to a certain extent, under WW conditions. We interpret that this relationship may have originated from genetic differences in the transpiration response to high $\mathrm{VPD}_{\max }$ in both crop species (Vadez et al. 2013, 2014) in these two seasons with medium-high evaporative demand. Interestingly, the correlations between $\mathrm{TE}$ and the residual yields unexplained by $\mathrm{HI}$ were tighter in the rainy than the post-rainy season. This may have been in part because the residuals were smaller in the post-rainy season (due to a greater dependence of yield on $\mathrm{HI}$ in that season), but also because the evaporative demand in the rainy season was medium to high and may have created an environment prone to differentiate genotypes that are either responsive or not to high $\mathrm{VPD}_{\max }$. By contrast, under the high evaporative demand of the post-rainy season, all genotypes would have been forced to respond in the same way (a restriction of transpiration under high $\mathrm{VPD}_{\max }$ ) to such harsh conditions. In any case, these data showed clearly the central importance of TE in the determination of yield in both crops, more so in cowpea than peanut.

\section{Water use in peanut and cowpea across season}

Peanut water use decreased greatly under WW in the rainy season compared with post-rainy season, whereas it did not change much in cowpea. This was despite the fact that haulm weight (and then very likely leaf area) was higher in the rainy season than in the post-rainy season in peanut. It might reflect that cowpea had a better capacity to restrict transpiration under high evaporative demand. Under stress, peanut also transpired more water than cowpea (192 v. $81 \mathrm{~mm})$, and appeared more sensitive to drought stress than cowpea. It was also interesting that there was no genotypic variation in the water use of peanut in the rainy season, whereas there were variations in cowpea. However, water use had no relationship to yield residuals in any of the crops. The drought resistance of cowpea could be due to its capacity to maintain higher relative water content to avoid dehydration by extracting moisture at low soil water content and decrease stomatal conductance and transpiration, thus leading to a net decrease in photosynthesis. Indeed, several studies (Pandey et al. 1984; Hall et al. 1997; Campos et al. 1999; Sarr et al. 2001; Ogbonnaya et al. 2003; Omae et al. 2005; Hamidou et al. 2007; Cardona-Ayala et al. 2013) show high stomatal control in cowpea, leading to a rapid closure of stomata under WS conditions. Of course, the high water requirement in peanut, because of a longer cycle than cowpea, led to higher yield than cowpea under WW conditions. Differences in water use were mostly due to differences in crop cycle duration and associated differences in evaporative demand, for instance, the 20 days elapsed between cowpea and peanut harvests. In any case, the data provided here on the plant water requirements under a range of environments and stress conditions provide a benchmark from which these crops can be best fitted to different rainfall environments. For instance, under water stress in a rainy season environment (high RH, moderate temperature), even a shorter duration cowpea would match peanut. Hence, the data are there to inform possible users about how these crops behave, how much water they need to grow to potential yield, how much of that potential is achieved if water is limiting, and how much of this potential is achieved if water is limiting and the environmental conditions are dry and hot. Therefore, although both peanut and cowpea are crops commonly grown in the Sahel, their water requirements clearly make them fit for different environments - cowpea for the more northern drier Sahelian zones, and peanut for higher rainfall, more southern area.

Based on higher pod yield criteria under stress conditions, some genotypes performed well in both seasons, whereas some genotypes performed in only one season. Genotypes ICG 4750 and ICGV 01232 for peanut and IT93K-93-10 for cowpea performed well under stress conditions across seasons. These genotypes can be selected for high pod production in both postrainy and rainy seasons. Genotypes ICGV 00350, ICG 97183 and JL 24 for peanut and IT98K-428-3 and IT96D-610 for cowpea revealed high pod yield in the rainy season, whereas ICG 8751 for peanut and Mouride and IT82E-18 for cowpea performed better in the post-rainy season. Independent of seasons, the top five genotypes under stress conditions were ICG 4750, ICGV 00350, ICG 97183, ICGV 01232 and ICG1 1088 for peanut and IT93K-93-10, Suvita2, IT98K-428-3, IT82E-18 and IT96D-610 for cowpea.

\section{Conclusion}

There were large species differences between peanut and cowpea. Thus, peanuts were more affected by seasonal fluctuation than cowpea. Genotypic variation in drought response was found for both species (peanut and cowpea). Peanut appeared to fit better to conditions with higher water availability and lower evaporative demand, whereas cowpea fitted well to harsher and dryer environments, suggesting that mechanisms of drought adaptation in peanut and cowpea were different. It is hypothesised that cowpea has a better capacity to restrict transpiration under high evaporative demand. TE could be good criteria for breeding peanut and cowpea under drought condition. Genotypes ICG 4750, ICGV 00350, ICG 97183, ICGV 01232 and ICG11088 for peanut and IT93K-93-10, Suvita2, IT98K-428-3, IT82E-18 and IT96D-610 for cowpea can be recommended under conditions of low rainfall for better pod yield production.

\section{Acknowledgements}

This work was supported by fund from the Bill and Melinda Gates Foundation (Tropical Legume Project-Phase 2) through a grant to the Generation Challenge Program. We are thankful to Dr L Krishnamurthy for his comments on an earlier version of the manuscript.

\section{References}

Ahmed FE, Suliman ASH (2010) Effect of water stress applied at different stages of growth on seed yield and water-use efficiency of cowpea. Agriculture and Biology Journal of North America 1, 534-540.

Belko N, Zaman-Allah M, Diop N, Cisse N, Zombre G, Ehlers J, Vadez V (2013) Restriction of transpiration rate under high vapour pressure deficit and non-limiting water conditions is important for terminal drought tolerance in cowpea. Plant Biology 15, 304-316. doi:10.1111/j.14388677.2012.00642.x

Belko N, Cisse N, Diop NN, Zombre G, Thiaw S, Muranaka S, Ehlers J (2014) Selection for postflowering drought resistance in short-and mediumduration cowpeas using stress tolerance indices. Crop Science 54, 25-33. doi:10.2135/cropsci2012.12.0685 
Blum A (2009) Effective use of water (EUW) and not water-use efficiency (WUE) is the target of crop yield improvement under drought stress. Field Crops Research 112, 119-123. doi:10.1016/j.fcr.2009.03.009

Boote K (1982) Growth stages of peanut (Arachis hypogaea L.) 1. Peanut Science 9, 35-40. doi:10.3146/i0095-3679-9-1-11

Cairns J, Sonder K, Zaidi P, Verhulst N, Mahuku G, Babu R, Nair S, Das B, Govaerts B, Vinayan M (2012) Maize production in a changing climate: Impacts, adaptation, and mitigation strategies. Advances in Agronomy 114, 1-58. doi:10.1016/B978-0-12-394275-3.00006-7

Campos PS, Ramalho J, Lauriano J, Silva M, do Ceu Matos M (1999) Effects of drought on photosynthetic performance and water relations of four Vigna genotypes. Photosynthetica 36, 79-87. doi:10.1023/A:100 7018804086

Cardona-Ayala CE, Jarma-Orozco A, Araméndiz-Tatis H, Perneth-Montaño M, Vergara-Córdoba CA (2013) Gas exchange and mass distribution of the cowpea (Vigna unguiculata [L.] Walp.) under water deficit. Agronomía Colombiana 31, 288-296.

Dadson R, Hashem F, Javaid I, Joshi J, Allen A, Devine T (2005) Effect of water stress on the yield of cowpea (Vigna unguiculata L. Walp.) genotypes in the Delmarva region of the United States. Journal of Agronomy \& Crop Science 191, 210-217. doi:10.1111/j.1439-037X. 2005.00155.x

DeLucia EH, Gomez-Casanovas N, Greenberg JA, Hudiburg TW, Kantola IB, Long SP, Miller AD, Ort DR, Parton WJ (2014) The theoretical limit to plant productivity. Environmental Science \& Technology 48, 9471-9477. doi:10.1021/es502348e

Duncan W, McCloud D, McGraw R, Boote K (1978) Physiological aspects of peanut yield improvement. Crop Science 18, 1015-1020. doi:10.2135/ cropsci1978.0011183X001800060028x

Ehlers J, Hall A (1997) Cowpea (Vigna unguiculata L. Walp.). Field Crops Research 53, 187-204. doi:10.1016/S0378-4290(97)00031-2

Ferris R, Ellis R, Wheeler T, Hadley P (1998) Effect of high temperature stress at anthesis on grain yield and biomass of field-grown crops of wheat. Annals of Botany 82, 631-639. doi:10.1006/anbo.1998.0740

Hall A, Thiaw S, Ismail A, Ehlers J (1997) Water-use efficiency and drought adaptation of cowpea. Advances in Cowpea Research 8, 87-96.

Hamidou F, Zombre G, Braconnier S (2007) Physiological and biochemical responses of cowpea genotypes to water stress under glasshouse and field conditions. Journal of Agronomy \& Crop Science 193, 229-237. doi:10.1111/j.1439-037X.2007.00253.x

Hamidou F, Ratnakumar P, Halilou O, Mponda O, Kapewa T, Monyo E, Faye I, Ntare B, Nigam S, Upadhyaya H (2012) Selection of intermittent drought tolerant lines across years and locations in the reference collection of groundnut (Arachis hypogaea L.). Field Crops Research 126, 189-199. doi:10.1016/j.fcr.2011.10.009

Hamidou F, Halilou O, Vadez V (2013) Assessment of groundnut under combined heat and drought stress. Journal of Agronomy \& Crop Science 199, 1-11. doi:10.1111/j.1439-037X.2012.00518.x

Jongrungklang N, Toomsan B, Vorasoot N, Jogloy S, Boote K, Hoogenboom G, Patanothai A (2011) Rooting traits of peanut genotypes with different yield responses to pre-flowering drought stress. Field Crops Research 120, 262-270. doi:10.1016/j.fcr.2010.10.008

Lobell DB, Bänziger M, Magorokosho C, Vivek B (2011) Nonlinear heat effects on African maize as evidenced by historical yield trials. Nature Climate Change 1, 42-45. doi:10.1038/nclimate1043

Morison J, Baker N, Mullineaux P, Davies W (2008) Improving water use in crop production. Philosophical Transactions of the Royal Society of London. Series B, Biological Sciences 363, 639-658. doi:10.1098/ rstb.2007.2175

Naveen P, Daniel KV, Subramanian P, Kumar PS (1992) Response of irrigated groundnut (Arachis hypogaea) to moisture stress and its management. Indian Journal of Agronomy 37, 82-85.

Ntare B, Diallo A, Ndjeunga J, Waliyar F (2008) 'Groundnut seed production manual.' (International Crops Research Institute for the Semi-Arid Tropics: Patancheru, India)
Nyakatawa E, Kamba E (1996) Productivity of maize and cowpea solecrop and intercrop systems on black vertisols of the South-East Lowveld of Zimbabwe. In 'Maize productivity gains through research and technology dissemination. Proceedings Eastern and Southern Africa Regional Maize Conference 5'. 3-7 June 1996, Arusha, Tanzania. (Eds JK Ransom, AFE Palmer, BT Zambezi, ZO Mduruma, SR Waddington, KV Pixley, DC Jewell) pp. 123-125.

Ogbonnaya C, Sarr B, Brou C, Diouf O, Diop N, Roy-Macauley H (2003) Selection of cowpea genotypes in hydroponics, pots, and field for drought tolerance. Crop Science 43, 1114-1120. doi:10.2135/cropsci2003.1114

Omae H, Kumar A, Egawa Y, Kashiwaba K, Shono M (2005) Genotypic differences in plant water status and relationship with reproductive responses in snap bean (Phaseolus vulgaris L.) during water stress. Japanese Journal of Tropical Agriculture 49, 1-7.

Pallas J, Stansell J, Koske T (1979) Effects of drought on Florunner peanuts. Agronomy Journal 71, 853-858. doi:10.2134/agronj1979. $00021962007100050034 \mathrm{x}$

Pandey R, Herrera W, Pendleton J (1984) Drought response of grain legumes under irrigation gradient: I. Yield and yield components. Agronomy Journal 76, 549-553. doi:10.2134/agronj1984.0002196200 7600040009x

Pandey RK, Morris RA, Whisler FD (1987) Water extraction patterns, water use and yield of ten upland crops following rainfed lowland rice in the tropics. Philippine Journal of Crop Science 12, 163-168.

Passioura J (1977) Grain yield, harvest index, and water use of wheat. Journal of the Australian Institute of Agricultural Science 43, 117-121.

Prasad PVV, Craufurd PQ, Summerfield RJ, Wheeler TR (2000) Effects of short episodes of heat stress on flower production and fruit-set of groundnut (Arachis hypogaea L.). Journal of Experimental Botany 51, 777-784. doi:10.1093/jexbot/51.345.777

Ratnakumar P, Vadez V (2011) Groundnut (Arachis hypogaea) genotypes tolerant to intermittent drought maintain a high harvest index and have small leaf canopy under stress. Functional Plant Biology 38, 1016-1023. doi:10.1071/FP11145

Ratnakumar P, Vadez V, Nigam S, Krishnamurthy L (2009) Assessment of transpiration efficiency in peanut (Arachis hypogaea L.) under drought using a lysimetric system. Plant Biology 11, 124-130. doi:10.1111/ j.1438-8677.2009.00260.x

Ravindra V, Nautiyal P, Joshi Y (1990) Physiological analysis of drought resistance and yield in groundnut (Arachis hypogaea L.). Tropical Agriculture, Trinidad and Tobago 67, 290-296.

Reddy T, Reddy V, Anbumozhi V (2003) Physiological responses of groundnut (Arachis hypogea L.) to drought stress and its amelioration: a critical review. Plant Growth Regulation 41, 75-88. doi:10.1023/ A:1027353430164

Rucker K, Kvien C, Holbrook C, Hook J (1995) Identification of peanut genotypes with improved drought avoidance traits 1. Peanut Science 22, 14-18. doi:10.3146/pnut.22.1.0003

Sanda AR, Maina IM (2013) Effect of drought on the yields of different cowpea cultivars and their response to time of planting in Kano State, Nigeria. International Journal of Environment \& Bioenergy 6, 171-176.

Sarr B, DioufO, Diouf M, Roy-Macauley H (2001) Utilisation des paramètres agromorphologiques comme critères de résistance à la sécheresse chez trois variétés de niébé cultivées au Sénégal et au Niger. Sécheresse 12, 253-266.

Sharma KK, Lavanya M (2002) Recent developments in transgenics for abiotic stress in legumes of the semi-arid tropics. JIRCAS Working Report No. 23. pp. 61-73. Japan International Research Centre for Agricultural Research.

Sinclair TR (2012) Is transpiration efficiency a viable plant trait in breeding for crop improvement? Functional Plant Biology 39, 359-365. doi:10. 1071/FP11198

Singh B, Mai-Kodomi Y, Terao T (1999) Relative drought tolerance of major rainfed crops of the semi-arid tropics. Indian Journal of Genetics and Plant Breeding 59, 437-444. 
Songsri P, Jogloy S, Vorasoot N, Akkasaeng C, Patanothai A, Holbrook C (2008) Root distribution of drought-resistant peanut genotypes in response to drought. Journal of Agronomy \& Crop Science 194, 92-103. doi:10.1111/j.1439-037X.2008.00296.x

Steduto P, Hsiao TC, Fereres E (2007) On the conservative behaviour of biomass water productivity. Irrigation Science 25, 189-207. doi:10.1007/ s00271-007-0064-1

Tomás M, Medrano H, Escalona JM, Martorell S, Pou A, Ribas-Carbó M, Flexas J (2014) Variability of water use efficiency in grapevines. Environmental and Experimental Botany 103, 148-157. doi:10.1016/j. envexpbot.2013.09.003

Turk KJ, Hall AE, Asbell C (1980) Drought adaptation of cowpea. I. Influence of drought on seed yield. Agronomy Journal 72, 413-420. doi:10.2134/agronj1980.00021962007200030004x

Vadez V, Krishnamurthy L, Kashiwagi J, Kholova J, Devi J, Sharma K, Bhatnagar-Mathur P, Hoisington D, Hash C, Bidinger F (2007a) Exploiting the functionality of root systems for dry, saline, and nutrient deficient environments in a changing climate. Journal of SAT Agricultural Research 4, 1-61.

Vadez V, Krishnamurthy L, Serraj R, Gaur P, Upadhyaya H, Hoisington D, Varshney R, Turner N, Siddique K (2007b) Large variation in salinity tolerance in chickpea is explained by differences in sensitivity at the reproductive stage. Field Crops Research 104, 123-129. doi:10.1016/j. fcr.2007.05.014

Vadez V, Rao S, Kholova J, Krishnamurthy L, Kashiwagi J, Ratnakumar P, Sharma K, Bhatnagar-Mathur P, Basu P (2008) Root research for drought tolerance in legumes: quo vadis. Journal of Food Legumes 21, $77-85$.

Vadez V, Deshpande SP, Kholova J, Hammer GL, Borrell AK, Talwar HS, Hash CT (2011a) Stay-green quantitative trait loci's effects on water extraction, transpiration efficiency and seed yield depend on recipient parent background. Functional Plant Biology 38, 553-566. doi:10.1071/ FP11073

Vadez V, Krishnamurthy L, Hash CT, Upadhyaya HD, Borrell AK (2011b) Yield, transpiration efficiency, and water-use variations and their interrelationships in the sorghum reference collection. Crop \& Pasture Science 62, 645-655. doi:10.1071/CP11007

Vadez V, Kholová J, Yadav RS, Hash CT (2013) Small temporal differences in water uptake among varieties of pearl millet (Pennisetum glaucum (L.) $\mathrm{R}$. Br.) are critical for grain yield under terminal drought. Plant and Soil 371, 447-462. doi:10.1007/s11104-013-1706-0

Vadez V, Kholova J, Medina S, Aparna K, Anderberg H (2014) Transpiration efficiency: new insights into an old story. Journal of Experimental Botany doi:10.1093/jxb/eru040

Wright G, Nageswara Rao R (1994) Groundnut water relations. In 'The groundnut crop'. pp. 281-335. (Springer: Berlin, Heidelberg)

Zaman-Allah M, Jenkinson DM, Vadez V (2011) A conservative pattern of water use, rather than deep or profuse rooting, is critical for the terminal drought tolerance of chickpea. Journal of Experimental Botany 62, 4239-4252. doi:10.1093/jxb/err139 